\title{
Peasant Associations and Agrarian Reform in Ethiopia
}

\section{Dawit Bekele}

In March 1975, a radical Land Reform Bill (LRB) was proclaimed in Ethiopia by a group of young military officers, NCOs and enlisted men (the 120-member Coordinating Committee of the Armed Forces, known as DERG) who had taken over state power on 12 September 1974 at the head of the popular movement of the February (1974) Revolution which overthrew a 2,000-year-old monarchy.

The basic provisions of the Bill were as follows:

- it abolished private property in rural land without compensation;

- the sale, mortgaging, lease or exchange of land were prohibited to prevent the reproduction of class relations based on property;

- it abolished all exploitation in agriculture (landlord-tenant relationships, wage-labour except for state farms and disabled persons) and moneylending;

- it abolished all land-based litigations in the judicial system (40 per cent of all court cases) and set up separate mass-based tribunals under the peasant associations with only one court of appeal as opposed to more than half a dozen during the monarchy;

- every working person was promised up to 10 hectares of arable land and the principle of equal distribution of land was proclaimed as well as the abolition of gender discrimination in land rights;

- it abolished the peasantry's debt to money-lenders, landlords, etc;

- it nationalised all large-scale capitalist farms and their machinery; about a third of them were distributed to evicted tenants and other landless groups.

It also declared the formation of producer and other cooperatives among the peasantry and allowed the formation of peasant associations (PAs) at local and regional levels from which landlords and other exploiting elements were barred from joining for at least a year. PAs were to be popular bodies for the implementation of the bill [POMOA 1976:18]. ${ }^{1}$

\footnotetext{
'Related bills included the PAs Organisation and Consolidation Bill $(14 / 12 / 75)$ (henceforth called Consolidation Bill), Agrarian Tax Bill (4/1/76), Producer Cooperative Guidelines (June 1979), National Peasant Association laws (September 1977), Nationalisation of large industries, banking, insurance, urban land and housing (January-July 1975), state monopolies on major internal and external trade and a National Democratic Revolution programme with a declared
} int ention of a transition to socialism.
Until PAs were set up and undertook land redistribution, every former tenant was to retain right of possession over land he or she tilled. Right to retain agricultural implements and a pair of oxen belonging to the landlord (the latter to be paid for over a threeyear period) was also guaranteed. The PA Consolidation Bill (December 1975) defined their functions as securing and safeguarding the political, economic and social rights of the peasantry, exercising self-rule, enabling the peasantry to participate in the struggle against feudalism and imperialism and for socialism; and creating organisations among the peasantry (women's associations, militia, units of production, consumption, etc).

The PAs consisted of a general assembly of all registered members which elected a nine-person executive committee. In turn, the committee elected a 20-person defence squad; a five-person tribunal was also independently elected by the Assembly. Legislative, executive and judicial functions overlapped and in most cases the executive tended to replace both the tribunal and the assembly.

Each PA was supposed to be set up at the local level on an area of 800 hectares, theoretically involving 400 persons (about 80 families). In reality, it varied between one or two hundred people in some areas and thousands in others. The Bill made provisions for district (Wereda) and county (Awraja) associations and a later proclamation in September 1977 extended this to provincial and national levels. By the end of 1976, 21,501 PAs had been set up in all provinces (except Eritrea) with the help of some 50,000 students and teachers sent to the rural areas to participate in a Development Campaign (Zemetcha) and also with the efforts of the district land reform officers of the Ministry of Land Reform. Most of these (about 18,000 ) were set up in the first three months after the LRB proclamation. By the end of 1978, this figure had risen to 25,583 with $7,275,507$ members, including Eritrea [Mulugetta Bezabeh et al 1978:84].

The Bill is often cited as one of the most radical ever declared. Among the reasons forwarded for such a claim are the contents of the Bill itself, the opposition of Chinese, Soviet and Western experts to it, the implementation drive involving a mass campaign of some 50,000 students and teachers and the violent suppression of rebelling landlords, etc. Moreover, the radicalism of the $L R$ and related bills, and its impact on the peasantry are made the basis for characterising

Bulletin, 1982, vol 13 no 4, Institure of Development Studies, Sussex 





the military regime in power as either socialist or a 'state of socialist orientation' [Molyneux and Halliday 1982]. Political forces opposed to the regime are either labelled 'rightist' or 'ultra-left'. National liberation struggles such as those waged in Eritrea, Oromia etc are dismissed as secessionist and therefore 'reactionary'.

Eight years after the promulgation of this Bill, however, a socialist agriculture has yet to emerge, cooperatives account for less than one per cent of agricultural production and $\mathbf{0 . 6}$ per cent of all farm households, equal land distribution has been abandoned, and the peasant associations have been taken over by rich peasants and transformed into organs of central state power with overlapping interests between the two. Agricultural production has shown no rise above population growth levels, famine is still endemic and in general, the economic, political and social impact of a radical land reform is nowhere in evidence.

This article intends to inquire why a supposedly 'radical' land reform lost its impetus. Specifically, it aims to clarify the political character of the LRB by examining the PAs as the main vehicle of implementation of the Bill. In examining the PAs, we should focus on the questions of mass mobilisation and participation, the exercise of real political power at grass-roots, their relationship to the central state structure, their class composition and their role in promoting the interests of the peasantry. Did the PA possess the degree of organisational autonomy necessary to defend the interests of the pesantry? Such an analysis of the PAs would also help us to understand the real political dynamics of the land reform as a whole, and assess the relationship between its declared goals and its political results.

\section{PAs and Land Redistribution}

Initially, the most important activity of the PAs was land distribution on behalf of the Ministry of Land Reform whose inability to implement the law was one of the main reasons for passing it over to the PAs. The 4 March Land Reform proclamation, through its decree on the formation of PAs seemed to herald the birth of a popular institution that would guarantee new peasant land-holdings. What are the prerequisities for such an equal distribution and what kinds of structure, methods and personnel are required to move from redistribution to collectivisation in a country where small-holder agriculture has been dominant for several hundred, and, in some cases, a thousand years? The source of land for equalisation of holdings and the social basis of the class to be dispossessed were of crucial importance. The process of distribution involved two phases. First, by abolishing tenancy and legitimising the holdings of every tenant operator the Land Reform Bill abolished absentee landlordism, resident landlords, and rich peasant holdings leased out to other tenants. This process redistributed land to poor tenants with the result that land was henceforth held by former tenants, middle peasants and rich peasants only. In effect, holdings of more than 10 hectares were abolished by the bill and some holdings of more than five hectares belonging to rich peasants but leased to tenants were also confiscated since, given the prevailing technology, a farmer could cultivate only about two to three hectares, with another two to three left for grazing. Of all the redistributive aspects of the $L R B$, this was probably the least turbulent since it involved holdings already operated by tenants, and the general opposition of the landlords and rural gentry had been broken.

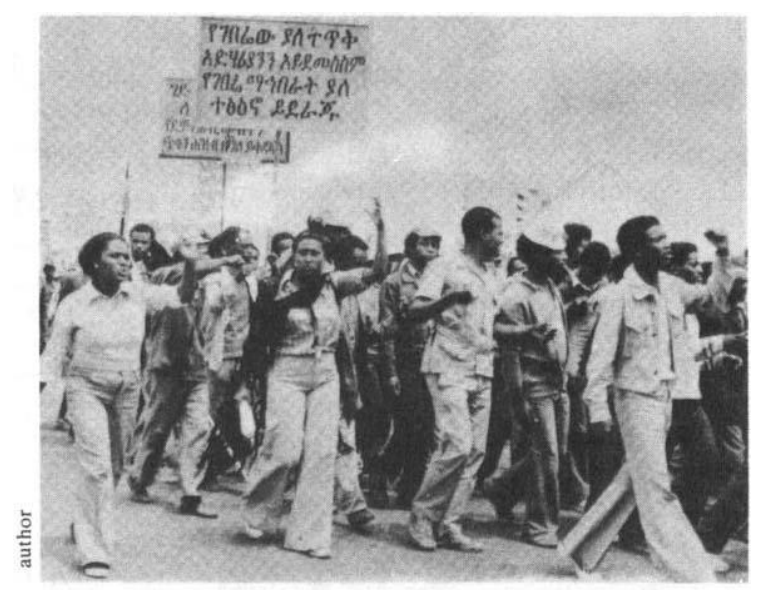

Movement for autonomous and democratic Peasant Associations. The suppression of this movement heralded the change in state policy towards the peasants.

The first phase of redistribution also included the allocation of previously commercial farms or newly converted state farms to landless tenants and other landless people and agricultural labourers. About 54,500 hectares of such land had been distributed by September 1975 [Ethiopian Herald, 13 September 1975]. The next phase of this policy would have involved taking land from the rich peasants and giving it to poor peasants and former tenants. This involved land holdings of between five and ten hectares and in some cases even less. The question thus arises: can the poor peasants and former tenants overcome the rich peasants? What would the role of the middle peasant be?

In fact the rich peasants are relatively well organised, armed, in control of the peasant associations and enjoy cordial relations with the police and bureaucracy. To break rich peasant control of the PAs in the 
north and the axis of old rich peasants and old middle peasants-turned-rich peasants in the south would require a far greater social transformation in the countryside than any that has taken place so far. It would also require a network of rural party or cadre organisations as has been the case in China or Vietnam, and a class strategy like that of China. This is a process of social revolution and on the central state level it requires a broad social base involving all the new democratic revolutionary forces and classes. In Ethiopia, the military government opted for such a policy in rhetoric, but in practice, five years after the proclamation we find that the policy of 'equal land distribution' has been abandoned [IBRD 1980].

As can be seen from Table 1, in 1975-76 more than half of the total number of holdings 52.2 per cent were less than one hectare in size each; these accounted for only 18.2 per cent of the total area of holdings. This picture had not changed much by 1976-77 when 48.3 per cent of holdings were still less than one hectare each and accounted for only 17.4 per cent of the total area. On the other hand, 24 per cent of the larger holdings (above two hectares) accounted for nearly 60 per cent of the total area of holdings.

The leadership of the PAs was taken over fully by the rich peasant class (in the north) in alliance with the upper middle peasants (in the south). Indeed, the June 1979 government guidelines on producers cooperatives (PCG) declared 'the leadership positions of peasant associations at the present time are occupied by rich and middle peasants .... By this time, five years after the February revolution and four years after the LRB, the majority of the peasantry, was disenchanted with the state and was moving away from the idea of collective farming.

\section{Peasant Associations and the Struggle for Autonomy}

As with many institutions that were products of the February 1974 Revolution, the PAs display varying feat ures which reflect the strategies of contending class forces and their degree of organisational clarity at different moments of the revolution. The original authors of the Land Reform Bill were a radical group of nine civilians in the Ministry of Land Reform, all of whom have now been purged or exiled. In their draft introduction to the constitution of the PAs, they stated prophetically that the nature of state power and its democratic basis were the decisive factors in determining whether these associations would be beneficial to the peasantry or not. Invoking the example of Franco's Spain, where the peasant committees formed during the Revolution were used to control and suppress the revolutionary peasant movement, they stressed that there was nothing intrinsically popular in the PAs themselves unless the upper reaches of state power were themselves the expression of popular intervention - a warning later deleted by the military regime.

After the proclamation of the Land Reform Bill, implementation at the local level faced serious opposition from landlords and local police forces. However, in the south, the peasantry and radical students in the Zemetcha combined to struggle against the local gentry and police. During this heyday of mass movements and radical policies, from March to June 1975, PAs and popular courts mushroomed. Landlords were disarmed and economic assets confiscated in some areas. At the height of the movement tens of thousands of peasants carried out insurrections in coordination with Zemetcha participants, teachers and workers groups in provincial towns.

Table 1

Size of holdings 1974-77

\begin{tabular}{lrcccc}
\hline year & holdings & under I.00 ha & I.0I.-5.00 & 5.01 and over & total holdings \\
\hline $74-75$ & no ('000) & 2064.0 & 1822.0 & 239.0 & 4127.0 \\
& $\%$ & 50.01 & 44.15 & 5.79 & 99.95 \\
$75-76$ & no ('000) & 2677.8 & 2246.9 & 205.1 & 5129.3 \\
& $\%$ & 52.20 & 43.80 & 4.00 & 100.00 \\
$76-77$ & no ('000) & 2237.4 & 2227.8 & 172.2 & 4637.4 \\
& $\%$ & 48.25 & 48.04 & 3.71 & 100.00 \\
\hline
\end{tabular}

Source: Mulugetta Bezabih et al, 1978, Agrarian Reform and Rural Development in Ethiopia, MOA/IDR, Addis Ababa, August, $\mathrm{p} 79$ 
Although the local police and state bureaucracy did everything in their power to protect the landlords, the weight of popular opposition and the confusion of state policy militated against them. This situation was drastically reversed by the military, starting with events in the south-western provincial capital of Jimma. Having realised the revolutionary implications of the popular movements, a top level delegation led by Major Sisay Habte launched a crackdown on the leaders of the PAs and radical Zemetcha participants. The state media launched a week of continuous propaganda discrediting the intentions and actions of the opposition. Many PAs with a radical past were banned, and their leaders arrested; others were forbidden to hold meetings.

The consolidation proclamation of the Bill on Rural Land (14 December 1975) seemed to herald a change of policy on the arming of the peasantry as it provided for the formation of defence squads under the PAs to be trained and armed by the government. But the function of the Consolidation Bill was in effect to negate the autonomy of the PAs by making them subordinate extensions of the Ministry of Interior below the district level through the creation of district Revolutionary Administrative and Development Committees to '. . . supervise the activit ies of peasant associations and any association established by such association within the Wereda' (article 47/4) [Bezabih et al 1978]. Each committee was chaired by the chief authority of the central government at the district level, the district administrator $(46 / 1)$, and dominated by other central government officials at the district level (such as the police chief). Peasant representation was weak - three members as against six government officials representing the central government. The intensification of the wars waged by the liberation movements in the second half of 1977 transformed the role of PAs. The primary pre-occupation of the state now became the recruitment of an army of hundreds of thousands to suppress this explosion. PA defence squads were rounded up to raise an army for the wars in Eritrea and Ogaden. In fact, the PAs became the instrument of mobilisation and recruitment for this army. The severity of the manpower demands of the war, the fate of the soldiers that entered this war machine and the doubts about its justness among broad setions of the oppressed classes soon alienated the peasantry from the war. In consequence, the PAs came to represent the insecurity of life instead of a guarantee of newly acquired rights of land-holding. Moreover, despite the legal proclamation of the lowest ever level of taxation for the peasantry, the PAs were transformed into a political instrument of massive fund-raising for the state.

PAs have not been able to function as agents of self or local government. They lack legislative powers even on internal matters and have no financial resources of their own nor forms of taxation to raise funds for local administrative or development projects - these would be basic functions of any local government. The executive function of the PAs consists in carrying out central government decisions at the local level. They cannot counterpose local interests versus the central government, nor are they accountable to the local population except in that local people elect them. Indeed, in many ways the PAs are a great innovation for the centralised state. First, they replace the traditional representatives of the ancien regime at the local level. Second, they are mass elected organs and thus attain a popular legitimacy. They carry out all the tasks of their predecessors and further they collect the taxes of the central government: like the Chikkashum the chairman of the PA can keep two per cent of the taxes. They undertake to arrest all persons violating the law and to hand over such persons to 'the appropriate authorities' (Consolidation Bill, 2/11-1); they carry out 'the necessary security and defence activities according to the decision of the government' (CB, 2/11/5); they follow land-use directives issued by the government (LRB, 3/10/2) and 'administer and conserve any public property within the area, especially the soil, water and forest', (also wildlife) (LRB, 3/10/3), mining lands, places of historical and antiquarian significance (LRR/3/10/9); and in all their activities which include 'the enforcement and execution of relevant laws and government policies' ( $\mathrm{CB}, 3 / 47 / 1)$ they are to be supervised $(C B, 4 / 47 / 4)$ by the district administrator $(\mathrm{CB} / 4 / 44 / 3$ and $4 \mathrm{~b} / \mathrm{a})$ and the district police chief $(C B / 4 / 46 / n)$. The district level PA is the key point of linkage with the state apparatus. The PAs above district level are ossified structures without any functions for the people or the state since no real decisions are taken at these levels [Mariam 1978]. Even judicial, tax collection, pension or land distribution activities are non-existent at these levels (though the Awraja has had some judicial functions). These organisations are cosmetic in that they will only contribute towards the growth of a peasant aristocracy with membership dues collected by the central government.

\section{Conclusion}

As institutions embodying elements of both the state apparatus and the peasantry, with organisational linkages to the state apparatus and the political organisations of the class in power, PAs pose a problem of identity. Whom and what do they represent? What is their relationship to land reform, to the state's declared intention of creating a socialist agriculture, and to the aspirations of the peasantry for land, equality, democracy and peace?

There is a clear incompatibility between their roles as mass organisations and as organs of state admini- 
stration. To further or defend the interests of their members, such associations would need to have considerable autonomy from hegemonic political forces. The degree of this autonomy, together with the level of internal democracy, determines whether these bodies will defend the interests of the groups they are designed to represent. In practice, this depends on the members' consciousness of their own political, social and economic interests.

The radicalism of the provisions of the land reform bill, the success in the formal organisation of the peasantry in PAs, and the abolition of the landlord class obscures the real nature of these PAs. Appearing as organs of self-rule, people's power and popular economic bodies in a socialist framework, they have been transformed into organs of central government with law and order, revenue collection, security and mobilisation functions. The participation and organisation of women in PAs has been marginalised and a de-politicisation of the peasantry has taken place with the take-over by rich peasants of PA leadership. This process is similar to what happened to the Ethiopian working class after the promulgation of the labour laws. The PAs cannot be taken as the expression of the political power of the peasantry. The nature of the PA is not determined by the body which has elected them to power or the class origins of the PA officers but by the nature of political power and hegemony at the level of the central state apparatus of which the PAs are the rural extension with very limited autonomy.

\section{References}

Berhane, G/Mariam, 1978, 'Strategies for socialist rural transformation in Ethiopia', seminar paper, IDR, Addis Ababa, October p 4

Bezabih, Mulugetta, et al, 1978, Agrarian Reform and Rural Development in Ethiopia, FAO/UN Rome, paper no 73, p 84

Ethiopian Herald, 1975, 13 September, Speech of Brig General Teferi Bante

IBRD, 1980, Economic Memorandum on Ethiopia, p 42, Annex $1-\mathrm{p} \mathrm{4,} 22$ April

Molyneux, Maxine and Fred Halliday, 1982, The Ethiopian Revolution, Verso, London

POMOA, 1976, Basic Document of the Ethiopian Revolution, Provisional Military Government of Socialist Ethiopia (PMGSE), Addis Ababa, p 18 